\title{
SOIL PROPERTIES AND NUTRIENT ELEMENT STATUS OF COCONUT LEAVES UNDER DEFFERENT CROPPING PATTERNS
}

\author{
Doah Dekok Tarigans ${ }^{1}$
}

\begin{abstract}
This study was conducted to investigate the effects of six coconut cropping patterns on the soil properties and nutrient element status of coconut leaves. The experiments were carried out from August 1984 to May 1985 in Silang, Cavite, Philippines. Data on-soil properties and nutrient element starus of coconut leaves were statistically analyzed in Randomized Block Design with three replications. Six cropping patterns in coconut with four species of perennial crops as intercrops, namely: banana, papaya, coffee and pineapple were used in this study. The organic matter, $\mathrm{pH}$ and cation exchange capacity of the soils did not differ significantly with cropping pattern although intensively cropped farms tended to have higher organic matter' and cation exchange capacity values. Nitrogen, phosphorus and potassium in the top soil were significantly higher in most intensive intercropped farms, but calcium and magnesium did not vary significantly. Moisture content, waterholding capacity, bulk density and particle density of the soil did not show significant difference with cropping patterns. Likewise, the number of bacteria, fungi and actinomycetes in the soil remained statistically the same. Leaf nitrogen and calcium, increased while potassium decreased with intensity of cropping. Phosphorus and magnesium showed no definite trend.
\end{abstract}

\section{INTRODUCTION}

Coconut as a monocrop results in lesser returns relative to its potential. Creencia (1978) suggested maximized utilization of coconut lands to provide a promising cushion from any future drop in the price of copra. He recommended multiple cropping as a solution to increase productivity of coconut land. Similarly, Nelliat et al (1974) pointed out that the most suitable way to increase productivity is through multiple cropping which would keep the photosynthetic factory to be operative at higher efficiency and longer time.

However, there is a general belief th-at intercropping in coconut lands results in nutrient deficiencies leading to an overan loss of returns.

Most intercrops grown, aside from being remunerative had no adverse effect on the growth and yield of coconut (Margate, 1978). The fact that intercropped lands were more productive than when solely planted can be attributed to the constant cultivation and fertilization made on the intercrops (Margate, 1978). Intercropping improves the production ranges from about 64 to 90 percent in.terms of nut and increases copra yield with one or more cropping combinations, ranging from 75-105 percent (Tarigans, 1985).

Despite all these advantages, there has not been any serious study on farming patterns with perennial crops conducted with regard to the soil properties and nutrient contents of coconut leaves. The objectives of the study were the following : (1) to study the effects of six cropping patterns of coconut on the soil properties, and (2) to study nutrient contents of coconut leaves of coconut with other crops.

\footnotetext{
${ }^{1}$ Farming Systems Agronomist, Agency for Agricultural Research and Development Research, Institute for Coconut, Jln. Cimanggu 1 Bogor, Indonesia.
} 


\section{MATERIAL AND METHODS}

There were a number of factors causing differences in the growth of palm and soil properties under field conditions. To cope with the existing variations in cropping patterns in relation to the growth of the palm and soil properties, the following criteria were recognized.

Age of the coconut palm and intercrop: With the coconut tree as base of cropping pattern, in this study the age of the variety is indexed by its height. The trunk of tall vadeties grows about one foot high in a year. This information supplemented by the farmers whose coconut farms were established 45-50 years ago was included in the area samples. Only perennial intercrops most commonly practised by the farmers in the area were used. Uniformity in age of each intercrop within cropping pattern was considered.

Topography of the area: The area of experiment was mostly plain and concentrated in one 'Barangay'.

Vigor of coconut tree and intercrop $(s)$ : Coconut trees and intercrops with good performance and free of pests and diseases were used in the final listing of sample farms. The plants with abnormalities resulting from nutrient deficiencies were excluded.

Variery of the coconut palm: Local tall variety which is typical in Laguna. Philippines was used in this study. Bole trunk is one of the criteria used in selection of the variety.

Type of intercrop(s): The intercrop(s) considered in the study were banana, papaya, coffee and pineapple. These crops were commonly pianted by the local farmers. The cropping patterns with these crops were also established.

Table 1.

Six cropping patterns as used for the study

\begin{tabular}{|c|l|l|}
\hline $\begin{array}{c}\text { Cropping } \\
\text { pattern }\end{array}$ & \multicolumn{1}{|c|}{ Crop planted } & \multicolumn{1}{|c|}{ Code } \\
\hline I & Coconut (control) & $\mathrm{cc}$ \\
II & Coconut + Pineapple & $\mathrm{cc} / \mathrm{pi}$ \\
III & Coconut + Coffee & $\mathrm{cc} / \mathrm{cf}$ \\
IV & Coconut + Papaya + Pineapple & $\mathrm{cc} / \mathrm{pa} / \mathrm{pi}$ \\
V & Coconut + Banana + Coffee & $\mathrm{cc} / \mathrm{b} / \mathrm{cf}$ \\
VI & Coconut + Banana + Papaya + Coffee + Pineapple & $\mathrm{cc} / \mathrm{ba} / \mathrm{pa} / \mathrm{cf} / \mathrm{pi}$ \\
\hline
\end{tabular}

Data

Chemical properties of the soil analyzed were, total nitrogen, available phosphorus, exchangeable potassium, exchangeable calcium, exchangeable magnesium, soil $\mathrm{pH}$, organic matter and cation exchange capacity.

Physical properties of the soil determined were bulk density, particle density, waterholding capacity and moisture content'of the soil.

Biological properties of the soil determined in this study included of bacteria, number of actinomycetes and number of fungi. 
Nutrient concentration of the leaves was measured by tissue analysis. Nutrition concentration of the leaves analyzed were nitrogen, phosphorus, potassium, calcium and magnesium.

\section{Sampling procedure}

Soil analysis: Laboratory analyses of soil samples for chemical, physical and biological were obtained from five pits that were dug randomly in every rephcation of cropping pattern. Two major horizons were sarnpled separately, namely topsoil with a depth of 0-40 cm and subsoil with $40-50 \mathrm{~cm}$ depth. In each layer between replication, a composite sample was obtained.

Leaf analysis: The sampling and preparation of leaf samples were adopted from Fremond et al (1966). The $14^{\text {th }}$ leaf was used as sample. This leaf can be picked in two ways :

1. Its petiole forms and angle of 450 with the axis of the trunk. The main part of the blade is practically horizontal and the top hangs down. Consequently the length of this leaf as projected on the ground is greater than that of any other.

2. The developing nuts of the bunch carried in the axil of leaf area. about the size of a fist. Should the nuts be missing (shed prematurely) one may rely on the fact that leaf no. 9 immediately above; carries an unopened inflorescence, contained in a swollen club-like sheath.

Leaf samples were gathered from the $14^{\text {th }}$ leaf and derived from five trees per replication of cropping pattern. From every sample tree, six leaflets were taken from near the midlenght of the blade-three from each side of the central rachis.

Procedure of analysis: Chemical and physical properties of soil were analyzed by following the standard method of analysis for soil, plant, tissue, water and fertilizers. However, the delution plate method was used for analysis of biological properties of the soil. Nitrogen, phosphorus, potassium, calcium and magnesitun were analysed from the leaf sample. The method used for soil analysis was the same procedural operation emploved in lleaf analysis, for the said.nutrient elements.

Statistical analysis: Data on soil chemical pararneters, soil physical properties, soil biological properties and leaf analysis were statistically analyzed in Randomized Complete Block Design (RCBD) with three repUcations. The hsd test was used in comparing the effects among the six cropping patterns.

\section{RESULTS AND DISCUSSION}

\section{Soil chemical properties}

The average organic matter in the top sod as affected by cropping pattern in coconut is presented in Table 2. Cropping pattern coconut/banana/coffee $(\mathrm{cc} / \mathrm{ba} / \mathrm{cf})$ had the highest organic matter content with an average of 2.70 percent, followed by cropping pattern coconut/banana/papaya/coffee/pineapple (cc/ba/ pa/cf/pi), coconut/papaya/pineapple (cc/pa/pi), and coconut monoculture (cc) with average of $2.58,2.49,2.23,2.19$ and 2.15 percent, respectively. When the means were compared, the differences were not statistically significant. However, all soils on cropping patterns had higher organic matter content compared to coconut monoculture. This may be due to the intercrops providing the basic materials to fonn humus or organic matter in the top soil. 
In the subsoil, cropping pattern $\mathrm{cc} / \mathrm{ba} / \mathrm{cf}$ had the highest organic matter content followed by cropping pattern cc/ba/pa/cf/pi, which averaged 1.97 and 1.83 percent, respectively. These are highly significantly different from those of cropping patterns $\mathrm{cc} / \mathrm{pa} / \mathrm{pi}$ and $\mathrm{cc} / \mathrm{pi}$. The organic matter content of soil in coconut monoculture was significantly higher than that of cc/cf but did not differ appreciably from the organic matter of the soils in other patterns of cropping.

Table 2.

Chemical properties of top and subsoil under six cropping patterns

\begin{tabular}{|c|c|c|c|c|c|c|}
\hline \multirow[b]{2}{*}{ Cropping patterns } & \multicolumn{2}{|c|}{$\mathrm{OM}$} & \multicolumn{2}{|c|}{$\mathrm{pH}$} & \multicolumn{2}{|c|}{ CEC } \\
\hline & $\begin{array}{l}\text { Top } \\
\text { soil }\end{array}$ & $\begin{array}{l}\text { Sub } \\
\text { Soil }\end{array}$ & $\begin{array}{l}\text { Top } \\
\text { Soil }\end{array}$ & $\begin{array}{l}\text { Sub } \\
\text { Soil }\end{array}$ & $\begin{array}{l}\text { Top } \\
\text { Soil }\end{array}$ & $\begin{array}{l}\text { Sub } \\
\text { Soil }\end{array}$ \\
\hline 1. Coconut monoculture & $2.15 a$ & 1.65ab & $5.27 a$ & $5.27 a$ & $33.86 a$ & 38.37ab \\
\hline 2. Coconut + pineapple & $2.49 a$ & $1.38 b c$ & $4.90 \mathrm{a}$ & $5.10 \mathrm{a}$ & $32.89 a$ & 38.44ab \\
\hline 3. Coconut + coffee & $2.23 a$ & $1.15 \mathrm{c}$ & $4.83 a$ & $5.03 a$ & $36.34 a$ & 40.49ab \\
\hline 4. Coconut + papaya + pineapple & $2.19 a$ & $1.37 \mathrm{bc}$ & $4.82 \mathrm{a}$ & $5.27 a$ & $34.67 a$ & $41.57 a$ \\
\hline 5. Coocnut + banana + coffee & $2.70 \mathrm{a}$ & $1.97 a$ & $5.07 a$ & $5.33 a$ & $34.14 a$ & $37.63 b$ \\
\hline $\begin{array}{l}\text { 6. Coconut + banana + Papaya }+ \\
\text { coffee + pineapple }\end{array}$ & $2.58 \mathrm{a}$ & $1.83 a$ & $5.03 a$ & $5.17 a$ & $38.38 a$ & $41.53 a$ \\
\hline CV (\%) & 10.16 & 10.99 & 5.09 & 4.97 & 7.49 & 3.06 \\
\hline
\end{tabular}

Note: $\mathrm{OM}=$ Organic matter $\quad$ CEC : Cation exchange capacity

Mean followed by a common letter(s) in each column is not significantly different at the $5 \%$ level.

In general, the data indicated that the mean organic matter content in the topsoil was higher than mean organic matter content in the subsoil. This may be due to accumulation of humus derived from the break down of plant materials on the soil surface. The application of plant part or crop residues on the soil increases soil organic matter (Miller and Amstad, 1971; Foth and Turk, 1974).

The reactions of the topsoil in different coconut cropping pattern were acidic, varying slightly with the cropping pattern. Soil $\mathrm{pH}$ in the topsoil tended to decrease in the presence of intercrops. This may be due to regular application of urea fertilizer being practiced in the farm and increased organic matter in the topsoil. The addition of urea tends ultimately to raise the acidity of the soil (Hausenbuiller, 1978). Agboola (1974) also reported that soil organic matter content was negatively correlated with $\mathrm{pH}$. This relationship was caused by gradual acidification as crop residues decomposed. Carbon dioxide released from the decomposition of crop residues reacted with water to produce carbonic acid that may also had contributed to soil acidification (Dhar, 1968). The generally higher $\mathrm{pH}$ in the subsoil may be due to less acidification in that layer since there was much less organic matter in it.

The cation exchange capacity in the topsoil did not vary significantly with cropping patterns although it was generally more with increased intensity of crops (Table 2). The cation exchange capacity of the subsoil, however, was significantly higher with $\mathrm{cc} / \mathrm{ba} / \mathrm{pa} / \mathrm{cr} / \mathrm{pi}$ and $\mathrm{cc} / \mathrm{pa} / \mathrm{pi}$ than $\mathrm{cc} / \mathrm{ba} / \mathrm{cf}$ cropping pattern.

The presence of more organic matter and lower $\mathrm{pH}$ in more intensively cropped patterns may account for the higher cation exchange capacity of the soils compared to monocropped coconut plantatiom It had been shown that an increase in soil organic carbon of 0.54 percent resulted in an increase cation. exchange capacity by $2.2 \mathrm{me} / 100 \mathrm{~g}$,soil (Jones, 1971). At low pH value, the permanent chargeg of the clay and a small portion of organic calloids held ions that can be replaced by cation exchange; under these conditions, the cation exchange capacity was generally low (Charreaus, 1974). 74). 
Cropping patterns in coconut significantly affected total nitrogen in topsoil with $\mathrm{cc} / \mathrm{ba} / \mathrm{pa} / \mathrm{cf} / \mathrm{pi}$ system having the highest (Table 3) and statistically the same as those of $\mathrm{cc} / \mathrm{ba} / \mathrm{cf}$, $\mathrm{cc} / \mathrm{pi}, \mathrm{cc} / \mathrm{pa} / \mathrm{pi}$ and cc/cf. Coconut monoculture system had the lowest total nitrogen in the topsoil.

Improvement of total nitropn in the topsoil by cropping patterns may be due to the regular applicatio of urea fertilizer being practiced in the farms and increased organic: matter. The application of crop residues increased soil organic matter (Miller and Amstad, 1971; Foth and Turk, 1974) and nitrogen derived from the breakdown of plant formed humus (Child, 1974). On the other hand, deficiency of organic matter coexists with the deficiency of nitrogen in the soil (Amma, 1977).

In the subsoil, however, cropping patterns cc/pa/pi and cc/ba/cf had significantly higher total nitrogen than cropping pattern cc/cf. The rest are intermediate and did not differ significantly from the above.

Table 3 shows that the more intensive the cropping pattern, the availability of phosphorus in the topsoil was higher. This was not the same in the subsoil where available phosphorus was lowest in the most systems and highest in $\mathrm{cc} / \mathrm{pa} / \mathrm{pi}$ and $\mathrm{cc} / \mathrm{ba} / \mathrm{cf}$. The significant difference was found at 5 and 1 percent levels.

In general, the $\mathrm{P}_{2} \mathrm{O}_{5}$ content in the soil for six cropping patterns studied was low. Cordova (1965) suggested that the critical level for $\mathrm{P}_{2} \mathrm{O}_{5}$ in the soil was about $10 \mathrm{ppm}$. Although low, the shghly Mgher $\mathrm{P}_{2} \mathrm{O}_{5}$ in the topsoil of intensively cropped areas my be due to the decomposed material available in that layer. The low $\mathrm{P}_{2} \mathrm{O}_{5}$ in the subsoil may be caused by the heavy uptake of the various crops in the most intensively cropped patterns.

Coconut farms with more, intensive cropping patterns tended to have higher $\mathrm{K}_{2} \mathrm{O}_{5}$ than less intensively cropped ones. This was true for both the topsoil and subsoil. This may be traced to higher organic matter produced in more intensively cropped patterns than in less intensively cropped ones. The available potassium, calcium and magnesium were increased by crop residues, mulch, and crop residue incorporation. (Agboola, 1974; Lal, 1975). Fagi (1980) reported that mulching with non-leguminous crop residues 21 did not only increase significantly the concentration of $\mathrm{K}^{+}, \mathrm{Ca}^{2+}$, and $\mathrm{Mg}^{2+}$ but also increased $\mathrm{Fe}^{2+}, \mathrm{Mn}^{2+}$, and when fertilized with urea.

The amount of $\mathrm{K}_{2} \mathrm{O}$ in the soil was sufficient when compared to the threshold value $(0.15$ $0.20 \mathrm{me} / 100 \mathrm{~g}$ ) as suggested by Ollagnier (1979). These results may explain why nut yield responded to potassium fertilization in the Philippines which was observed uncommon since most of the soil has adequate potassium needed by palm (Magat, 1976).

The average, exchangeable calcium in the topsoil ranged from 8.90 to 10.92 (Table 3). The highest was observed in cropping pattern cclba/pa/cf/pi foBowed by $\mathrm{cc} / \mathrm{ba} / \mathrm{cf}$, coconut monoculture, $\mathrm{cc} / \mathrm{pa} / \mathrm{pi}, \mathrm{cc} / \mathrm{cf}$ and $\mathrm{cc} / \mathrm{pi}$ with average exchangeable calcium of 10.59, 10.02, 9.89, 9.03 and 8.90 $\mathrm{me} / 100 \mathrm{~g}$, respectively. Analysis of variance, nonetheless, showed insignificant differences among means, indicating that, this parameter in the topsoil was not affected by cropping pattern in coconut. In the subsoil, however, a significant difference was observed between cropping pattern cc/pa/pi and coconut monoculture, but neither was significantly different from cropping pattern $\mathrm{cc} / \mathrm{ba} / \mathrm{cf}$, $\mathrm{cc} / \mathrm{ba} / \mathrm{pa} / \mathrm{cf} / \mathrm{pi}, \mathrm{cc} / \mathrm{pi}$ and $\mathrm{cc} / \mathrm{cf}$. Further, the results showed that average exchangeable calcium in the soil increased with depth. This finding may explain higher $\mathrm{pH}$ in the subsoil compared to the topsoil.

The highest exchangeable magnesium in the topsoil was observed in cropping pattern $\mathrm{cc} / \mathrm{ba} / \mathrm{cf}$ while the lowest was in cc/ ba/pa/cf/pi pattern with averages of 6.94 and $5.94 \mathrm{me} / 100 \mathrm{~g}$, respectively. Statistically, however, cropping pattern effect means were just comparable, indicating 
that exchangeable magnesium in the topsoil was not influenced by cropping pattern in coconut. Magnesium in the subsoil is neither significantly affected by cropping pattern but is generally higher than $\mathrm{MgO}$ in the topsoil. This finding revealed antagonistic characteristic between cations $(\mathrm{Mg}, \mathrm{Ca}$, and $\mathrm{K}$ ) in the subsoil than the topsoil. Casico (1983) reported strong antagonism between $\mathrm{Mg}$ and $\mathrm{Ca}$ against K in Philippines coconut soil. However, Escritor (1954) suggested that the trend in the concentration of magnesium was different from that of the other elements. The low yielding soils had more magnesium than the high yielding ones.

Table 3

Nutrient element status of top and subsoil under six cropping system

\begin{tabular}{|c|c|c|c|c|c|c|c|c|c|c|}
\hline \multirow[b]{2}{*}{$\begin{array}{l}\text { Cropping } \\
\text { patterns }\end{array}$} & \multicolumn{2}{|c|}{ N (\%) } & \multicolumn{2}{|c|}{$\mathrm{P}_{2} \mathrm{O}_{5}(\%)$} & \multicolumn{2}{|c|}{$\mathrm{K}_{2} \mathrm{O}(\mathrm{me} / 100 \mathrm{~g})$} & \multicolumn{2}{|c|}{$\mathrm{CaO}(\mathrm{me} / 100 \mathrm{~g})$} & \multicolumn{2}{|c|}{$\mathrm{MgO}(\mathrm{me} / 100 \mathrm{~g})$} \\
\hline & $\begin{array}{l}\text { Top } \\
\text { Soil }\end{array}$ & $\begin{array}{l}\text { Sub } \\
\text { Soil }\end{array}$ & $\begin{array}{l}\text { Top } \\
\text { Soil }\end{array}$ & $\begin{array}{l}\text { Sub } \\
\text { Soil }\end{array}$ & $\begin{array}{l}\text { Top } \\
\text { Soil }\end{array}$ & $\begin{array}{l}\text { Sub } \\
\text { Soil }\end{array}$ & $\begin{array}{l}\text { Top } \\
\text { Soil }\end{array}$ & $\begin{array}{l}\text { Sub } \\
\text { Soil }\end{array}$ & $\begin{array}{l}\text { Top } \\
\text { Soil }\end{array}$ & $\begin{array}{l}\text { Sub } \\
\text { Soil }\end{array}$ \\
\hline $\begin{array}{l}\text { 1. Coconut } \\
\text { monoculture }\end{array}$ & $0.103 b$ & $0.080 \mathrm{ab}$ & $3.16 \mathrm{~b}$ & $4.21 \mathrm{a}$ & $0.77 \mathrm{~b}$ & $0.433 b$ & $10.02 a$ & $11.42 \mathrm{~b}$ & $6.77 a$ & $7.49 a$ \\
\hline $\begin{array}{l}\text { 2. Coconut + } \\
\text { pineapple }\end{array}$ & $\begin{array}{r}0.120 \mathrm{a} \\
\mathrm{b}\end{array}$ & $0.083 a b$ & $3.28 b$ & $2.23 b$ & $1.11 \mathrm{ab}$ & $0.990 a$ & $8.90 \mathrm{a}$ & $12.51 \mathrm{ab}$ & $6.54 a$ & $7.55 a$ \\
\hline $\begin{array}{l}\text { 3. Coconut + } \\
\text { coffee }\end{array}$ & $0.107 a$ & $0.060 \mathrm{~b}$ & $3.76 \mathrm{~b}$ & $2.58 \mathrm{~b}$ & 1.19ab & $1.243 a$ & $9.03 a$ & $12.17 a b$ & $6.00 \mathrm{a}$ & $7.14 a$ \\
\hline $\begin{array}{l}\text { 4. Coconut + } \\
\text { papaya + } \\
\text { coffee }\end{array}$ & 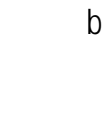 & $0.087 a$ & 4.33ab & $5.03 a$ & $1.56 a$ & $1.230 \mathrm{a}$ & $9.89 a$ & $13.31 a$ & $6.01 a$ & $7.99 a$ \\
\hline $\begin{array}{l}\text { 5. Coconut + } \\
\text { banana + } \\
\text { coffee }\end{array}$ & $\begin{array}{r}0.107 a \\
b\end{array}$ & $0.097 a$ & $6.14 a$ & $4.95 a$ & $1.42 a$ & $1.090 \mathrm{a}$ & $10.59 a$ & $12.88 a b$ & $6.94 a$ & $7.17 a$ \\
\hline $\begin{array}{l}\text { 6. Coconut + } \\
\text { banana + } \\
\text { papaya + } \\
\text { coffee + } \\
\text { pineapple }\end{array}$ & $0.130 \mathrm{a}$ & $0.083 a b$ & $6.44 a$ & $1.92 \mathrm{~b}$ & $1.34 a$ & $1.017 \mathrm{a}$ & $10.92 a$ & $12.64 a b$ & $5.94 a$ & $8.29 a$ \\
\hline CV (\%) & 8.853 & 11.178 & 18.382 & $\begin{array}{r}11.29 \\
6\end{array}$ & 17.259 & 14.446 & 8.799 & 4.924 & $\begin{array}{r}16.69 \\
7\end{array}$ & 5.83 \\
\hline
\end{tabular}

\section{Physical properties}

Analysis of variance showed no significant difference among cropping pattern with respect to water content (Table 4). Croppingpatterns in coconut did not significantly affect the percentage of moisture content in the topsoil. Similarly in the subsoil, moisture content was slightly varied, ranging from 14.11 to 17.67 percent from $\mathrm{cc} / \mathrm{ba} / \mathrm{cf}$ and $\mathrm{cc} / \mathrm{pi}$ system.

The data implied that the cropping patterns under study did not significantly affect the moisture content in the soil. The results were, possibly caused by relatively low orgartic matter and depth of solum of the soil under six cropping patterns. The less organic matter content in the soil, the lower was the moisture, content. The depth of solum exerted profound influence in the amount of water available for use. Under a dry environment, very likely the palms on shallow soils will be subjected to a longer period of moisture stress than those plams on the deep soil. Extreme moisture regimes, affected the coconut trees in a number of ways. To a large extent it promoted abortion of spathe while low moisture disturbed nitrification and badly affected the activity of the absorbing 
root system (Ollagnier, 1979). This condition could be a contributory factor in the yellowing of palm and low nut yield (Tolentino, 1980).

Table 4.

Physical properties of top and subsoil under six cropping patterns

\begin{tabular}{|c|c|c|c|c|c|c|c|c|}
\hline \multirow{2}{*}{$\begin{array}{l}\text { Cropping } \\
\text { Patterns }\end{array}$} & \multicolumn{2}{|c|}{$\begin{array}{c}\text { Moisture Content } \\
(\%)\end{array}$} & \multicolumn{2}{|c|}{$\begin{array}{l}\text { Water Holding } \\
\text { Capacity (\%) }\end{array}$} & \multicolumn{2}{|c|}{$\begin{array}{c}\text { Bulk Density } \\
(\mathrm{g} / \mathrm{cc})\end{array}$} & \multicolumn{2}{|c|}{$\begin{array}{l}\text { Particle Density } \\
(\mathrm{g} / \mathrm{cc})\end{array}$} \\
\hline & $\begin{array}{l}\text { Top } \\
\text { Soil }\end{array}$ & $\begin{array}{l}\text { Sub } \\
\text { Soil }\end{array}$ & $\begin{array}{l}\text { Top } \\
\text { Soil }\end{array}$ & $\begin{array}{l}\text { Sub } \\
\text { Soil }\end{array}$ & $\begin{array}{l}\text { Top } \\
\text { Soil }\end{array}$ & $\begin{array}{l}\text { Sub } \\
\text { Soil }\end{array}$ & $\begin{array}{l}\text { Top } \\
\text { Soil }\end{array}$ & $\begin{array}{l}\text { Sub } \\
\text { Soil }\end{array}$ \\
\hline $\begin{array}{l}\text { 1. Coconut } \\
\text { Monoculture }\end{array}$ & $16.80 \mathrm{a}$ & $15.96 \mathrm{a}$ & $72.71 \mathrm{a}$ & $71.29 a$ & $1.18 a$ & $1.23 a$ & $2.76 \mathrm{a}$ & $2.82 \mathrm{a}$ \\
\hline $\begin{array}{l}\text { 2. Coconut + } \\
\text { pineapple }\end{array}$ & $18.20 \mathrm{a}$ & $17.67 \mathrm{a}$ & $75.87 a$ & $67.09 a$ & $1.29 a$ & $1.38 \mathrm{a}$ & $2.81 \mathrm{a}$ & $2.84 a$ \\
\hline $\begin{array}{l}\text { 3. Coconut + } \\
\text { Coffee }\end{array}$ & $17.36 \mathrm{a}$ & $14.4 \mathrm{a}$ & $78.16 \mathrm{a}$ & $69.69 a$ & $1.22 \mathrm{a}$ & $1.29 a$ & $2.81 \mathrm{a}$ & $2.82 \mathrm{a}$ \\
\hline $\begin{array}{l}\text { 4. Coconut + } \\
\text { Papaya + } \\
\text { pineapple }\end{array}$ & $15.00 \mathrm{a}$ & $17.48 \mathrm{a}$ & $73.78 a$ & $73.64 a$ & $1.23 a$ & $1.30 \mathrm{a}$ & $2.79 a$ & $2.82 \mathrm{a}$ \\
\hline $\begin{array}{l}\text { 5. Coconut }+ \\
\text { banana }+ \text { coffee }\end{array}$ & $13.77 a$ & $14.11 \mathrm{a}$ & $74.81 \mathrm{a}$ & $74.36 a$ & $1.10 \mathrm{a}$ & $1.16 \mathrm{a}$ & $2.74 a$ & $2.78 \mathrm{a}$ \\
\hline $\begin{array}{l}\text { 6. Coconut + } \\
\text { banana + coffee } \\
+ \text { pineapple }\end{array}$ & $13.83 a$ & $15.19 a$ & $74.78 a$ & $74.27 a$ & $1.43 a$ & $1.18 \mathrm{a}$ & $2.73 a$ & $2.82 \mathrm{a}$ \\
\hline C.V (\%) & 13.551 & 12.957 & 5.067 & 5.835 & 11.736 & 9.741 & 1.745 & 2.380 \\
\hline
\end{tabular}

The waterholding capacity of the topsoil, generally is slightly higher than the waterholding capacity of the subsoil. This was because the former had higher organic matter than the latter. The waterholding capacity of the topsoil ranged from 72.71 percent in the coconut monoculture pattern to $78.16 \mathrm{in} \mathrm{cc} / \mathrm{cf}$ while in the subsoil, waterholding capacity ranged from 67.08 to $74.36 \mathrm{with} \mathrm{cc} / \mathrm{pi}$ and $\mathrm{cc} / \mathrm{pa} / \mathrm{pi}$, respectively. In both cases, cropping pattern did not significantly affect waterholding capacity.

The bulk density of top and subsoil, varied slightly among cropping patterns. Analysis of variances; for both soil layers showed no significant difference between cropping patterns (Table 4). This finding suggests that cropping patterns in coconut did not significantly affect the bulk density in the soil.

The highest particle, density in the topsoil was observed in cropping patterns $\mathrm{cc} / \mathrm{pi}$ or $\mathrm{cc} / \mathrm{cf}$ while the lowest was in $\mathrm{cc} / \mathrm{ba} / \mathrm{pa} / \mathrm{cf} / \mathrm{pi}$ pattern with averages 2.81 and $2.73 \mathrm{~g} / \mathrm{cc}$, respectively. Statistically, however, cropping pattern,effects on particle density were just comparable, indicating that particle density in the topsoil was not infiuenced by cropping patterns in coconut. While, particld density in the subsoil was significantly affected by cropping patterns and genemUy higher than particle density in the topsoil. This finding confirmed the fact that topsoil has higher organic matter content than the subsoil. Brady (1984) suggested that surface soil wMch almost always has higher organic matter content an the subsoil, usually possessed lower particle densities than the subsoils.

\section{Biological properties}

The number of bacteria in the topsoil under six cropping patterns did not differ significantly. Bacterial mean count ranged from 104,000 (the lower) for cropping pattern cc/pi to 
128,700 for $\mathrm{cc} / \mathrm{cf}$ (Table 5). It is apparent that.bacterial count in the topsoil was not sigafficantly enhanced by the intensity of cropping patterns in coconut.

Bacterial count in the subsoil, however, was highest $(72,667)$ in cropping pattern cc/pi and lowest $(65,967)$ in coconut monoculture. No significant variations were observed among cropping patterns, suggesting that cropping patterns did not influence the bacterial count in the subsoil. The data indicated that bacterial count in the soil decreased greatly with depth. These results conformed with those of Alexander (1977) who suggested the number dedines with greater depth.

Fungal count in the top and subsoil as affected by cropping pattern is presented in Table 5. Cropping pattern cc/pi had the highest $(319,667)$ fungal count which was slightly higher than that of coconut monoculture $(304,333)$. cc/ba/cf pattern had the lowest $(263,333)$. Statistically, however, treatment means were just comparable, indicating that number of fungi was not appreciably influenced by cropping patterns in coconut.

The fungal population in the subsoil did not differ significantly although it was highest in $\mathrm{cc} / \mathrm{ba} / \mathrm{pa} / \mathrm{cf} / \mathrm{pi}(57,400)$ and lowest in cc/cf $(53,333)$. This suggested that cropping pattern did not affect the amount of fungi in the subsoil. In general, the results indicated that fungal population in the soil tend to decrease with depth. This was possible due to a decrease in organic matter with soil depth. Moreover, the data indicated that fungal population dominated the biological properties of the topsoil. These fmdings conformed with that of Alexander (1977) who suggested that the microbial community in areas of low $\mathrm{pH}$ was dominated by the fungi. This was not because the fungi find acidic condition optimum for their growth but instead it was a consequence of the lack of microbiological competition for the good reserve. Thus, the intensitivity of many of the fungi to high hydrogen ion concentrations and narrow $\mathrm{pH}$ range of most bacteria and actinomycetes, the fungi make up a larger percentage of the community and are responsible for a considerable portion of the biochemical transformation in acid habitats.

The number of actinomycetes in the topsoil as affected by coconut cropping patterns varied slightly (Table 5). It ranged from 16,467 for coconut monoculture to $19,200 \mathrm{for} \mathrm{cc} / \mathrm{ba} / \mathrm{cf}$ pattern. Actinomycetes population in the subsoil, is about $1 / 3$ of the topsoil but the general trends were about the same. These results implied that intercropping in coconut slightly but not significantly improved actinomycetes population in the topsoil.

Actinomycetes were affected directly by the presence of available carbon and their number was especially great in soils rich in organic matter. In general, sites high in organic matter or humus have larger numbers than habitats poor in organic matter (Alexander, 1977). The difference in the organic matter of the soils in this study, particularly the topsoils, may not have been enough to support significantly differing populations of the microorganisms.

\section{Leaf nutrient status of coconut palms}

The highest nitrogen concentration of coconut leaf under six cropping patterns was observed in cc/pi while the lowest was in coconut monoculture (cc) pattern with average of 1.91 and 1.52 percent, respectively (Table 6). Statistically, however, the means were just comparable, indicating that nitrogen concentration of coconut leaves was not influenced by cropping pattern. Further, the. data indicated that all coconut palms with intercrop(s) had higher percentage of nitrogen in their leaves compared to those under monoculture. This was due to the increased organic matter with intercrop(s) and regular application of urea fertilizer practiced in these farms. Nitrogen concentration in the coconut leaves under coconutmonoculture (cc) and cc/cf pattern were found to be below the critical. level for $\mathrm{N}$ for normal nut production (Fremond et. al, 1966), while $\mathrm{N}$ concentration of coconut leaves on the other cropping patterns were within the normal range $(\mathrm{N}$ $=1.8$ to $20 \%$ ). 
Table 5.

Biological properties of top and subsoil under six cropping patterns

\begin{tabular}{|c|c|c|c|c|c|c|}
\hline \multirow{2}{*}{$\begin{array}{c}\text { Cropping } \\
\text { Pattern }\end{array}$} & \multicolumn{2}{|c|}{ Number of Bacteria } & \multicolumn{2}{|c|}{ Number of fungi } & \multicolumn{2}{|c|}{ Number of Actinomycetes } \\
\hline & Topsoil & Subsoil & Topsoil & Subsoil & Topsoil & Subsoil \\
\hline $\begin{array}{l}\text { 1. Coconut } \\
\text { Monoculture }\end{array}$ & $117,667 a$ & $65,967 a$ & $304,333 a$ & $55,267 a$ & $16,467 a$ & $5,333 a$ \\
\hline $\begin{array}{l}\text { 2. Coconut + } \\
\text { pineapple }\end{array}$ & $104,000 a$ & $72,667 a$ & $319,667 a$ & $53,667 a$ & $18,973 a$ & $5,733 a$ \\
\hline $\begin{array}{l}\text { 3. Coconut + } \\
\text { coffee }\end{array}$ & $128,700 a$ & $67,100 \mathrm{a}$ & $273,333 a$ & $53,333 a$ & $18,817 a$ & $5,367 a$ \\
\hline $\begin{array}{l}\text { 4. Coconut + } \\
\text { papaya }+\end{array}$ & $111,300 a$ & $66,467 a$ & $301,000 \mathrm{a}$ & $56,667 a$ & $17,733 a$ & $5,600 \mathrm{a}$ \\
\hline pineapple & $122,067 a$ & $70,300 a$ & $263,333 a$ & $53,833 a$ & $19,200 a$ & $6,533 a$ \\
\hline $\begin{array}{l}\text { 6. Coconut + } \\
\text { banana + papaya } \\
+ \text { cofee }+ \\
\text { pineapple }\end{array}$ & $116,333 a$ & $67,067 a$ & $269,000 \mathrm{a}$ & $57,400 \mathrm{a}$ & $17,267 a$ & $6,367 a$ \\
\hline C.V. (\%) & 13.753 & 13.859 & 21.381 & 10.671 & 21.598 & 11.177 \\
\hline
\end{tabular}

The phosphorus concentration in the coconut leaves was not affected by the type of cropping pattern (Table 6). Coconut with pineapple (cc/pi) had the highest concerntration of $\mathrm{P}$ in the leaves $(0.15 \%)$, while those from other cropping patterns had the same concentration $(0.13 \%)$. However, the $\mathrm{P}$ concentration of the leaves of palm in all cropping patterns was within the satisfactory levels (0.12) for coconut as suggested by Magat (1976). This suggests that application of inorganic phosphorus fertihzer as unfavourable.

The potassium concentration of the coconut leaves did not vary significantly with different cropping patterns (Table 6), although the data ranged from 0.63 percent in $\mathrm{cc} / \mathrm{ba} / \mathrm{cf}$ to 1.08 percent in monocropped farm. Cropping patterns with banana and pineapple have $\mathrm{K}$ concentration in coconut leaves lower than the critical level (0.80 percent) as indicated by Kanapathy (1977). This suggested that these two crops, which contain fiber in their biomass, competed more strongly fir K with the coconut palms. Banana had been reported to be a heavy feeder of nutrients particularly potassium (Anonymous, 1977). Coconut palms with coffee or in monoculture have sufficient $\mathrm{K}$ in their leaves for normal frowth and production, but those in the former pattern have barely enough $\mathrm{K}$ in their leaves. This suggested that the presence of coffee reduces $\mathrm{K}$ in the nutrient uptake of the palms. But this reduction is greater where pineapple and bana are intercropped with the palms. This means that $\mathrm{K}$ must be supplied in greater quantity where coconut palms are interplanted with these crops.

Leaf $\mathrm{Ca}$ concentration was Mghest (0.19 percent) in cropping pattern cc/ba/pa/cf/pi and lowest ( 0.15 percent) in coconut monoculture and cc/pi pattern (Table 6). No significant variation was observed in leaf $\mathrm{Ca}$ among cropping pattern, suggesting that cropping patterns did not influence the $\mathrm{Ca}$ concentration in the leaves. The Ca concentration of the leaves in all cropping patterns, how ever, were lower than the critical level (0.30 percent) as suggested by Magat (1976). Anunciado (1974) and Santiago (1983) reported that Ca concentration in the leaves decreased with reduced rainfall. The data indicated that generally $\mathrm{K}$ and $\mathrm{Ca}$ concentration in the leaves were low, implying that the results did not follow the synergysm between K-Ca as proposed by Ziller and Prevot (1962) who reported that $\mathrm{K}-\mathrm{Mg}$ synergysm exists when percentage of $\mathrm{K}$ is low. These observations indicated that $\mathrm{Mg}$ fertilizer can be utilized by the coconut palms to improve nutrient balance in the leaf. 
Like the other elements considered in the study, Mg level in the leaves was not affected by cropping patterns in coconut (Table 6). Coconut monoculture (cc), however, had the highest $(0.20$ percent) $\mathrm{Mg}$ concentration while $\mathrm{cc} / \mathrm{pa} / \mathrm{pi}$ and $\mathrm{cc} / \mathrm{ba} / \mathrm{pa} / \mathrm{cf} / \mathrm{pi}$ had the lowest ( 0.17 percent). The rest had 0.19 percent. Magnesium concentration in the coconut leaves for aH cropping patterns, however, were close to the critical level ( 0.20 percent) for nut production as suggested by Magat (1 976). As in $\mathrm{Ca}$, this result did not foRow the synergysm effect between $\mathrm{K}-\mathrm{Mg}$ as proposed by Mer and Prevot (1962) who reported that K-Mg synergysm exists when percentage of $\mathrm{K}$ is low. These observations indicated that $\mathrm{Mg}$ fertilizer can be utilized by the coconut palms to improve nutrient balance in the leaf.

Table 6.

Nutrient contents of coconut leaves under six cropping patterns

\begin{tabular}{|l|c|r|r|r|r|}
\hline \multicolumn{1}{|c|}{ Cropping Patterns } & \multicolumn{1}{c|}{$\begin{array}{c}\mathrm{N} \\
(\%)\end{array}$} & \multicolumn{1}{c|}{$\begin{array}{c}\mathrm{P} \\
(\%)\end{array}$} & \multicolumn{1}{c|}{$\begin{array}{c}\mathrm{K} \\
(\%)\end{array}$} & \multicolumn{1}{c|}{$\begin{array}{c}\mathrm{Ca} \\
(\%)\end{array}$} & \multicolumn{1}{c|}{$\begin{array}{c}\mathrm{Mg} \\
(\%)\end{array}$} \\
\hline 1. Coconut Monoculture & $1.52 \mathrm{a}$ & $0.13 \mathrm{a}$ & $1.08 \mathrm{a}$ & $0.15 \mathrm{a}$ & $0.20 \mathrm{a}$ \\
2. Coconut + pineapple & $1.91 \mathrm{a}$ & $0.15 \mathrm{a}$ & $0.70 \mathrm{a}$ & $0.15 \mathrm{a}$ & $0.19 \mathrm{a}$ \\
3. Coconut + coffee & $1.72 \mathrm{a}$ & $0.13 \mathrm{a}$ & $0.82 \mathrm{a}$ & $0.16 \mathrm{a}$ & $0.19 \mathrm{a}$ \\
$\begin{array}{l}\text { 4. Coconut + papaya+ pine apple } \\
\text { 5. Coconut + banana + coffee }\end{array}$ & $1.86 \mathrm{a}$ & $0.13 \mathrm{a}$ & $0.74 \mathrm{a}$ & $0.17 \mathrm{a}$ & $0.17 \mathrm{a}$ \\
$\begin{array}{l}\text { 6. Coconut + banana + papaya + } \\
\text { coffee + pineapple }\end{array}$ & $1.82 \mathrm{a}$ & $0.13 \mathrm{a}$ & $0.63 \mathrm{a}$ & $0.18 \mathrm{a}$ & $0.19 \mathrm{a}$ \\
\hline C.V. $(\%)$ & $0.13 \mathrm{a}$ & $0.65 \mathrm{a}$ & $0.19 \mathrm{a}$ & $0.17 \mathrm{a}$ \\
\hline
\end{tabular}

Note: Means followed by a common letter(s) in each column are not significantly different at the $5 \%$ level.

\section{CONCLUSIONS}

The organic matter of the topsoil was practically the same under various cropping patterns but the subsoil has higher organic matter in more intensely cropped areas. The $\mathrm{pH}$ and topsoil cation exchange capacity did not also differ but cation exchange capacity in the subsoil varied widely.

Nitrogen phosphorus and potassium in the topsoil were significantly higher in the most intensive intercropped farms than monocropped coconut areas. Calcium and magnesium did not differ significantly, except in the subsoil where calcium was also lowest in the monocropped are as.

The moisture content, waterholding capacity, bulk density and particle density of the soil in the various cropping patterns in coconut did not vary significantly.

The microbial population in terms of bacteria, fungi and actinomycetes in the soils of the various patterns of culture in coconut did not differ significantly.

The nutrient concentration of the coconut leaves under six cropping patterns differed only slightly, with nitrogen and calciurn increasing with faming intensity and potassium decreasing. Phosphorus and magnesium showed no relation with cropping intensity. 


\section{REFERENCES}

AGBOOLA, A. A. (1974). Problem of improving soil fertility by the use of green manuring in the tropical fanning system. Report of the FAO/SIDA Expert Consultation on Organic Material as Fertilizers. FAO Soil Bull. 27: 147-163.

ALEXANDER, M. (1977). Introduction to Soil Microbiology. 2nd Edition. John Willey and Sons. New York, Santa Barbara, London, Sydney, Toronto.

AMMA, B. S. K. (1977). Soil organic matter. The need for its enrichment. Indian Coconut J.8(6): $1-2$.

ANONYMOUS. (1977). The Philippines recomendations for pineapple. Philippines Council for Agricultural Research.

,( 1980). Standard methods of analysis for soil, plant tissue, water and fertilizer. Philippine Council for Agriculture and Resource Research, Los Banos, Laguna.

(1984). Coconut-Based Farming Systems: Status and Prospects. Ajoint publication of the Farming Systems and Soil Resources Institute, College of Agriculture University of the Philippines at Los Banos, College, Laguna and the Philippine Coconut Authority, Diliman, Quezon City.

ANUNCIADO, I. S. (1974). Coconut button and fruit abscission in relation to palm nutrition. M.S. Thesis, UPLB, College, Laguna, Philippines.

BAVAPPA, K. A. V. and V. J. JACOB. (1982). A new approach to small-scale farming in the tropics. High intensity multispecies cropping. World Crops. 34(2): 47-50.

BRADY, N. C. (1984). The Nature and Properties of Soil. Ninth Edition. McMillan Publishing Company, New York. Collier McMillan Publishers London.

CARLOS, M. B. (1 983). The economics of coconut based integrated farming systems in Silang, Cavite. B. S. Thesis, UPLB, College, Laguna, Philippines.

CHARREAUS, C. (1 974). Organic matter and biochemical properties of soils in the dry tropical zone of West Africa. Report of the FAO/SIDA Expert Consultation on Organic Material as Fertilizers. FAO Soil Bull 5: 488-492.

CHILD, R. 1974). Coconut. Longman. 345p.

CORDOVA, A. S. (1965). The soil chemical status and foliar nutrient composition of coconut trees in some Philippines Coconut Plantation. M.S. Thesis, UPLB, College, Laguna, Philippines.

COSICO, W. C. (1983). Land and soil evaluation of areas planted to coconut (Cocos nucifera L.) in the Philippines. Ph.D. Thesis, UPLB, College, Laguna, Philippines.

CREENCIA, R. P. (1978). Coconut-Based Multiple Cropping. Inaugural Professorial Lecture, July 26, 1978. INSAET Lecture Hall, University of the Philippines at Los Banos, College, Laguna, Philippines. 
DHAR, N. R. (1968). The value of organic matter phosphate and sunlight in nitrogen fixation and fertility improvement in world soils. pp. 243-350. In Study Week on Organic Matter and Soil Ferfility. New York: John Willey and Sons, Inc.

ESCRITOR, M. L. (1 954). Some physical and chemical properties of soils in coconut plantation in Gumaca, Phil. Agric. 38: 334-354.

FAGI, A. M. 1980). Physiochemical properties of rainfed rice soils as affected by croppingsystems and crop residue management, Ph.D. Thesis, UPLB, College, Laguna, Philippines.

FOTH, H. D., and L. M. Turk (1974). Fundamental of soil science. New York, John Willey and Sons, Inc. 454p.

FREMOND, Y., R. ZILLER and de NUCE de LAMOTHE. (1966). The coconut palm. Intemational Potash Inst. Beme/Switzerland.

HAUSENBUILLER, R. L. (1978). Soil Sciences. Principles and Practices. Wm. C. Brown Company Publishers. Dubuque. IOWA.

JONES, M. V. (1971). The maintenance of soil organic matter under continous cultivation at Samaru Nigeria. J. Agric. Sci. 77:473-483.

KANAPATHY, K. (1977). Preliminary work on foliar analysis as a guide to the manuring of coconuts. Conference soil and the water management. Int. Inst. Trop. Agric. Tech. Bull. 1: 38p.

LAL, R. (1975). Role of mulching Techniques in tropical soil and water management. Intemational Institute. Trop. Agric. Tech. Bulletin 1: 38p.

MAGAT, S. S. (1976). Soil and leaf analysis in relation to coconut yield. Phil. Jour. Coconut Studies $1(2): 1-9$.

MARGATE, L. Z. (1978). Intercropping studies at the Philippine Coconut Authority. Paper presented during the Fifth National Coconut Consultation: Cultural Management, PCA Davao Research Center, Nov. 24-25, 1978.

MILLER, D. E., and V. S. AMSTAD. (1971). Furrow infiltration rates as affected by incorporation of straw or furrow cultivation. Soil Sci. Soc. Amer. Proc. 34: 492-495.

NELLIAT, E. V., K. V. BAVAPPA, and P. K. R. NAIR. (1974). Multistoryed Cropping: A New Dimension Cropping for Coconut Plantation. World Crops 26(6): 262-266.

OLLAGNIER, M. (1979). Mineral nutrition and fertilization of the coconut in the world. Fifth session of the FAO Technical Working Party on Coconut Production, Protection and Processing, Manila, Philippines.

SANTIAGO, R. M. (1983). Toddy yield of coconut as influenced by fertilization, leaf nutzients, water status, climate factors, and morphological character. Ph.D. Thesis, UPLB, College, Laguna, Philppines.

TARIGANS, D. D. (1985). Effect of cropping patterns on the growth and production of coconut. Pemberitaan Penelitian Tanaman Industri Vol. X (3-4), Januari-Juni 1985. 
TOLENTINO, C. T. (1980). Utilitarian classification of soils for coconut production. Ph.D. Thesis. UPLB, College, Laguna. Philippines.

ZILLER, P., and P. PREVOT. (1962). Fohar diagnosis. A method of studying mineral nutrient its application to coconut palm. Indian Coconut Jour. 15 (3/4): 156-159. 